This work is licensed under a Creative Commons Attribution 4.0 International License.

Ovaj rad dostupan je za upotrebu pod međunarodnom licencom Creative Commons Attribution 4.0.

https://doi.org/10.31820/f.33.2.3

Dubravka Zima

\title{
ANARKISTE U VIENCU: LITERARNI OPUS VLADIMIRA MAŽURANIĆA ${ }^{1}$
}

dr. sc. Dubravka Zima, Sveučilište u Zagrebu, Fakultet hrvatskih studija dzima@hrstud.hr iD orcid.org/0000-0001-8874-5637

izvorni znanstveni članak

UDK 821.163.42.09Mažuranić, V. rukopis primljen: 17. ožujka 2021; prihvaćen za tisak: 25. studenoga 2021.

U članku se interpretira literarni opus Vladimira Mažuranića, koji je tijekom 1870-ih i 1880-ih godina surađivao u Viencu_književnim prilozima i esejima, a 1883. napisao dramu Grof Ivan, nagrađenu na natječaju Matice hrvatske. U književnom se radu Mažuranić bavio tzv. ženskim pitanjem (o čemu je objavio tri članka u Viencu) i ruskom književnošću (članak o Turgenjevu $i$ nihilizmu), napisao je nekoliko prigodnih $i$ sentimentalnih pjesama te komediju o anarhizmu. U članku se njegov književni opus kontekstualizira s obzirom na aktualnost njegovih književnih i društvenih interesa, uključujući $i$ činjenicu da komediju o anarhistima Mažuranić piše u vrijeme zagrebačkog suđenja anarhistima koje je privuklo veliku javnu pozornost.

Ključne riječi: Vladimir Mažuranić; Vienac; nihilizam; Turgenjev; anarhisti; anarhizam

Vladimir Mažuranić, otac Ivane Brlić-Mažuranić i sin Ivana Mažuranića, u hrvatskoj je kulturnoj i političkoj povijesti zabilježen zahvaljujući svojim pravno-povijesnim i filološkim istraživanjima, kao i po svojim političkim funkcijama: petnaestak je godina bio predsjednik Banskoga stola, najvišeg

1 Članak je prerađena i nadopunjena inačica eseja pročitanog u emisiji Kozmopolis na Trećem programu Hrvatskog radija u ožujku 2021. 
suda u Hrvatskoj na prijelomu stoljeća, u jednom mandatu (1918. - 1921.) i predsjednik JAZU, počasni član nekoliko slavenskih akademija. No prije nego što je njegova odvjetnička, sudačka te naposljetku znanstvena karijera krenula uzlaznim putem, u mladenačkim godinama, Vladimir je, po svemu sudeći, koketirao i s književničkim zanimanjem: u Viencu je u 1870-ima i 1880-ima objavio desetak književnih tekstova, od čega jednu komediju u pet prizora, a dramu Grof Ivan objavljuje 1883. kao zasebnu knjižicu u izdanju Matice hrvatske. $U$ to je doba već zaposlen kao voditelj urbarskog odsjeka Zemaljske vlade, te će nakon 1884, kako se čini, napustiti književne ambicije, unekoliko slijedeći i očev umjetnički i intelektualni put - Ivan Mažuranić također već do sredine svojih tridesetih godina života više-manje zaokružuje književni opus i okreće se politici. Vladimir, pak, u svojim zrelim tridesetim godinama prestaje objavljivati književnost. Do kraja stoljeća objavio je još dulji, dokumentarni i informativni tekst o kazališnom djelovanju svojega ujaka Dimitrije Demetra kao predgovor Demetrovoj Teuti (1891), čiju će neobjavljenu dramu također i prirediti i objaviti u Viencu 1901, no nakon početka novoga stoljeća sve se više okreće radu na svojemu magnum opus, Pravno-povijesnom rječniku na kojem će nastaviti raditi do pred kraj života.

Mažuranić je u Viencu prvi puta objavio članak već u drugom godištu, 1870. godine, a, ako je suditi po prilozima u Viencu, u to ga je doba zanimalo žensko obrazovanje. O toj je aktualnoj temi objavio čak tri članka, odnosno zapise tri predavanja što ih je tijekom 1870. i 1871. održao u Karlovcu i Zagrebu za „krasan spol”. Prema Mažuranićevu biografu (Jureković 2015), u tim je godinama mladi, tek završeni pravnik zaposlen u Karlovcu i Zagrebu, te radi u odvjetničkoj i sudačkoj struci. Tek će 1873. biti premješten u Ogulin, gdje će raditi kao državni odvjetnik, a u travnju iduće godine dobit će svoje prvo dijete, kćer Ivanu. Doduše, prema razmjerno pouzdanim, ali neadekvatno referiranim podacima o Vladimirovoj obitelji - prema kratkom memoarskom zapisu njegove druge kćeri Aleksandre (v. Zima 2019: 21) - Vladimir i njegova supruga, Varaždinka Henrietta r. Bernath, imali su ukupno osmero djece, no samo je četvero preživjelo ranu dojenačku dob. Od tih je četvero najstarija i najpoznatija Ivana Mažuranić koja će po udaji za Vatroslava Brlića svome prezimenu dodati još i muževljevo. No Aleksandrini zapisi ne otkrivaju kada su se vjenčali Vladimir i Henrietta i jesu li dobili i izgubili dijete ili djecu prije ili poslije Ivanina rođenja, što znači da ne možemo znati je li mladi Vladimir, u vrijeme kada drži ambiciozna, emotivna, afektivna predavanja krasnome spolu u Zagrebu i Karlovcu, već suprug i roditelj ili se na to tek priprema. 
Članak „Tudja književnost naprama našem narodu”, objavljen 1870. u 16. broju Vienca, u svojem se središnjem dijelu bavi Vladimirovim razmišljanjima o socijalnim i odgojnim perspektivama za žensko biće hrvatskog naroda. U predavanju koje je održao za „krasni spol” 23. ožujka 1870. (vjerojatno u Zagrebu) Mažuranić ukratko predstavlja milim, slabo obrazovanim drugaricama osnove europskih književnosti, no više se bavi aktivizmom: zagovaranjem aktivnijeg ženskog sudjelovanja u kulturnoj, a posebice književnoj kreativnosti:

Priskočite nam u pomoć. Gdje se radi o ikakovu pothvatu narodnu, neka budem tako sretan, da vidim u prvih redova učestnika i vas, gospodje moje. Dobre volje treba, prije svega pak poznavanja jezika. Uvrstite se zatim u razriedjene redove naših književnika, prinesite u književnost našu onaj ukus, koji joj manjka, poglavito morda baš zato manjka, jer se ljepša i bolja polovica naroda našega, jer se vi, gospodje moje, nepridružiste najnovijemu pokretu u Hrvatskoj. Znate li što bi bio vrhunac želja mojih? Hrvatska George Sand. A želja ta nije prevelika, izpunjenje nije nemoguće. Pun je darova ženski spol naroda našega; vi gospodje moje, koje ste domovini našoj barem ljepotom uviek slave pribavili, dočim smo mi mužkarci - nu stid me je dalje govoriti (Mažuranić 1870: 254).

Mažuranićeva želja za hrvatskom George Sand djeluje donekle začudno: premda je književni opus skandalozne, slobodoumne francuske književnice i socijalistkinje uživao ogromnu popularnost za njezina života, Mažuranić strateški ne eksplicira njezino subverzivno, društveno-izazivačko naličje. Sandova je gotovo tri desetljeća - od 1830-ih do 1860-ih godina - književno aktivna dok istovremeno izaziva i osporava rodne stereotipe na gotovo svim zamislivim razinama. Mažuranićev oprezni demarkativ „hrvatska" možda upućuje na hrvatsku rekontekstualizaciju književnih i izvanknjiževnih kvaliteta izravne, neustrašive i radikalne Sandove, čija je vršnjakinja i tada još živa Dragojla Jarnević skrovito također ispisivala skandalozne dnevničke zapise, ali čiji javni književni rad - knjigu pripovijedaka Domorodne poviesti (1843) i roman Dva pira objavljivan u nastavcima u karlovačkom Domobranu tijekom 1864. - Mažuranić očito ne ocjenjuje dovoljno vrijednim da ponese naziv hrvatske George Sand.

I u drugom predavanju održanom u listopadu iste godine i objavljenom u Viencu u 44. broju 1870, Vladimir također krasnome spolu predaje o književnosti: članak pod naslovom Književnost i sloboda kratak je pregled 
povijesti književnosti od antike do suvremenosti, točnije do romantizma čiji se epistemološki, poetološki i idealistički krakovi još osjećaju u vrijeme Mažuranićeve mladosti: upravo će Goethe biti jedan od istaknutijih figurasimbola slobode koje Mažuranić navodi u predavanju. Pojam slobode o kojem je riječ u predavanju pritom je politički denotiran i idealistički konotiran, a tiče se odnosa pisca i vlasti, od najstarije, grčke književnosti, preko rimske, pa do klasicističke francuske i romantičarske njemačke literature. S obzirom na oskudne ženske obrazovne mogućnosti i trendove, posebice izvan građanske klase, predavanje je nesumnjivo imalo i pragmatičnu, didaktičnu funkciju, osim završne idealističke poante, u kojoj se veliča, pa i zahtijeva, autorska sloboda bez uplitanja vlasti.

I u trećem predavanju, održanom u Narodnom domu u Karlovcu u ožujku 1871. Mažuranić se obraća ženama, govoreći ovoga puta o socijalnom položaju žena. Članak je pod naslovom „O socijalnom stanju žena” objavljen iste godine u 15. broju Vienca. U uvodu Mažuranić naglašava da ne zastupa nužno sve ideje koje navodi, nego da su diskursi koje prenosi (filozofski, politički, socijalni) uobičajeni i aktualni, no ne nužno i ispravni. $\mathrm{Na}$ taj način, rekla bih, nastoji razobličiti ideološki proces kojim se tradicionalne, esencijalističke ideje o društvenim rodnim identitetima prezentiraju kao prirodne i univerzalne; Mažuranić implicitno hvali novu, devetnaestostoljetnu poduzetničku ideologiju koja potiče žensko obrazovanje i snažniju društvenu i kulturnu participaciju i stoga je smatra modernijom, naprednijom i svakako boljom od tradicionalnog podcjenjivačkoga odnosa prema ženama, premda se još ne mogu pokazati osobiti rezultati u tome procesu, budući da još nema dovoljno visokoobrazovanih žena. ${ }^{2}$ Novo doba, smatra

2 U ovom je kontekstu zanimljivo upozoriti da se Mažuranićevo zagovaranje višeg ženskog obrazovanja ili barem rasprava o njemu zbiva u periodu intenzivnijeg društvenog zanimanja za žensko obrazovanje, zaokruženim donošenjem modernog Zakona ob ustroju pučkih škola i preparandija u listopadu 1874, za banovanja Vladimirova oca Ivana Mažuranića, kojim se obrazovanje djevojčica bitno unapređuje u odnosu na dotadašnje stanje. Prije toga mogućnosti ženskoga obrazovanja bile su izrazito oskudne; prvi značajniji, organiziraniji i javni napor oko obrazovanja djevojaka datira od kraja 18. stoljeća odnosno od terezijanske reforme školstva, iskazane Općim školskim redom iz 1774. Prije toga na prostoru Habsburške Monarhije školskoga sustava nije bilo (Župan 2013: 61), a djevojčice - maleni broj njih koje su dobile ikakvu školsku naobrazbu - školovale su se u konfesionalnim školama i/ili institucijama. U Zagrebu sestre klarise vode školu za djevojčice od 1646., u Varaždinu uršulinke od 1703., a od 1770-ih nekonfesionalne (javne) djevojačke škole otvaraju se u Karlovcu i Osijeku (ibid.). U kasnom 18. i tijekom 19. stoljeća paralelno postoji konfesionalno niže i više djevojačko obrazovanje i rudimentarni javni školski sustav, no najveći je problem u kontekstu 
Mažuranić, promijenit će i poboljšati staru, neprikladnu regulaciju i nepravedno ograničavanje ženske političke participacije; njegova je argumentacija u tome pitanju vrlo zanimljiva i, rekla bih, prilično reprezentativna za novu, mladu, ambicioznu građansku intelektualnu klasu:
A nit nije odlučno za sudbinu žene pitanje, hoće li joj se dozvolit pravo da glasuje, pravo da se zastupa sama pred sudom. Istina je, da su razlozi, kojim se načelna pravednost ovoga zahtieva pobijat kani, jako problematične vriednosti. U politiku se, kažu na primjer, žene miešat nesmiju, jer su odveć ćutljive, a politka hladan razbor zahtieva. Oprostite, gospodo moja prigovaratelji, gore od nas mužkaraca mislim da se nebi mogle ni najćutljivije žene okoristit političkom slobodom (ibid.: 239).

Argumenti koje navodi Mažuranić zagovarajući ženska politička prava - a koji se, već i s obzirom na autoritet iskazivača koji drži javno predavanje, mogu smatrati, barem unekoliko, kao valjani argumenti koji zastupaju javno mnijenje (dakle mušku javnost) - odnose se na ženin emocionalni rad, koji tradicionalisti smatraju nezaobilaznim u obiteljskom okružju, no pogubnim u političkom kontekstu. Za razliku od toga, Mažuranić, zastupajući nov, moderan, napredan pristup ženskom pitanju, osporava upravo

djevojačkoga obrazovanja roditeljski otpor slanju djevojčica u školu, čak i osnovnu. Ta će se situacija promijeniti tek u završnici 19. stoljeća, nakon što se obavezno četverogodišnje obrazovanje propisano spomenutim Školskim zakonom 1874. postupno počinje provoditi i davati rezultate. Kako pažljivo analizira i pokazuje Dinko Župan, premda je obrazovni program ponuđen važnom školskom reformom koja je ishodila iz tzv. Mažuranićeva zakona iz 1874. nudio neke progresivnije momente u djevojačkom obrazovanju poput veće tjedne satnice iz nedomaćinskih predmeta, snažna kritika toga programa s različitih pozicija i iz različitih društvenih slojeva rezultirala je novom reformom sredinom 1880-ih godina, fiksiranom Zakonom ob uredjenju pučke nastave i obrazovanja pučkih učitelja iz 1888, u kojoj se donekle progresivni program iz prethodnog desetljeća reducira te se ne samo smanjuje opseg nastavnog sadržaja i broj zadaća za djevojke, nego se i pojačavaju obrazovni sadržaji iz domaćinstva. (Župan 2005: 370-371) Kako navodi Ida Ograjšek Gorenjak (2006), do druge polovice 19. stoljeća obrazovni standard za djevojčice predstavlja četiri godine školovanja u nižoj pučkoj školi, a obrazovni maksimum - koji je završavalo samo 1 \% djevojaka u Hrvatskoj - odnosi se na osam godina školovanja, odnosno pohađanje više djevojačke škole u rijetkim hrvatskim gradovima koji su imali tu mogućnost. Kratkotrajno razdoblje djelovanja Ženske obrtne škole u Zagrebu koja je djelovala u okrilju Više djevojačke škole i pružala naobrazbu iz ženskog ručnog rada, te nešto duže djelovanje djevojačke preparandije pri Samostanu sestara milosrdnica u Zagrebu sve do 1890-ih godina predstavlja najviši doseg promišljanja o višem obrazovanju za djevojke. 
muški, racionalni princip, smatrajući ga u najmanju ruku jednako štetnim u političkom kontekstu.

Mažuranić se zalaže za žensko obrazovanje i za ženski pristup tržištu rada kako bi se žena po potrebi mogla sama uzdržavati, no ipak smatra da ne mora svaka žena imati stališ (zanimanje). No za društveni je napredak upravo žensko obrazovanje od presudne važnosti, jer će tek obrazovana žena moći odgojiti novu, napredniju, moderniju generaciju, što je karakterističan i vrlo uobičajen devetnaestostoljetni argument zagovornika boljeg ženskog obrazovanja. Ženin je duševni rad, smatra Mažuranić, njezina najsvetija zabava i najvažnija odgovornost.

Nakon 1871. Mažuranić se punih 12 godina ne javlja u Viencu - u tome je periodu njegova karijera napredovala od odvjetničkog koncipijenta u Karlovcu, preko državnog odvjetnika u Ogulinu, dožupana u Karlovcu, kratkotrajnog angažmana kod austrijske okupacije Bosne i Hercegovine $u$ svojstvu civilnog adlatusa, potom dožupana u Jastrebarskom, pa sve do zaposlenja na rukovodećem mjestu urbarskog odsjeka u Odjelu za unutarnje poslove Zemaljske vlade u Zagrebu (Jureković 2015). Paralelno, i obitelj mu je rasla: od proljeća 1874. do ljeta 1882. dobio je četvero djece, dvije kćeri i dva sina. Jedna će se od tih kćeri pojaviti u pjesmi Napast, objavljenoj u Viencu 1884. u trećem broju. U godinama 1883. i 1884. Mažuranić će u Viencu objaviti još pet tekstova: tri pjesme, odulji članak o Turgenjevu i jednočinku u pet prizora Anarkiste. 1891. godine objavit će u 52. broju i izvadak iz opširnog, informativnog i referentnog predgovora o kazališnom djelovanju Dimitrije Demetra - koji je u Vienčevoj bibliografiji (Anon.) pogrešno pripisan njegovom ocu Ivanu. Godine 1901. objavljuje u Viencu u pet nastavaka Demetrovu neobjavljenu dramu i time će završiti svoju suradnju s Viencem.

U 1880-ima Mažuranićevi literarni interesi poprilično se razlikuju od onih koje je istraživao prethodnoga desetljeća: prvo će njegovo javljanje u Viencu, nakon dvanaestogodišnje pauze, u 19. broju 1883. biti posvećeno Turgenjevu i nihilizmu u ruskoj književnosti. U oduljem članku Mažuranić podrobno predstavlja i analizira Turgenjevljev opus postavljajući ga u kontekst aktualnog duhovnoga stanja epohe, pri čemu je izvjesno da je barem dio toga opusa čitao na ruskom izvorniku. Prema Tomi Maretiću (1904), veliki je dio Turgenjevljeva opusa do toga doba već preveden na hrvatski ili srpski, premda većinu tih prijevoda Maretić ocjenjuje neadekvatnima, nepreciznima, pa i „traljavima”, te nije isključeno da se Mažuranić okreće izvornicima čak i kada postoje dostupni prijevodi. 
Turgenjev, istančan i pronicav motritelj ruskoga naroda, Mažuraniću je idealna platforma za analizu ne samo književnih trendova na prijelazu iz romantizma u realizam, nego i za interpretacije socijalnih, filozofskih i svakodnevnih misaonih trendova 19. stoljeća. Pritom je zanimljivo da Mažuranić, idealistički i donekle naivno, njegovoj književnosti pripisuje izravan socijalno-politički utjecaj, smatrajući djelovanje Lovčevih zapisa moćnije da raskinu okove kmetom, nego sva naša državnopravna i naravnopravna književnost (Mažuranić 1883a: 325). On je, naime, pisao od srca, iskreno, istinito, pisao je i risao, kako umije risati pravi umjetnik, ter, gle čuda, vlastela ruska porumeniše od stida, kad im, svemu svietu na vidiku, umjetnik prietećim prstom pokaza sliku, iz koje je svaka bolna crta dizala obtužbu; što učiniste od tolikih milijuna? (ibid.)

Turgenjev je, usprkos nihilizmu koji prikazuje u svojoj književnosti (a koji je, po Mažuranićevom tumačenju, isto što i anarhizam - želi uništiti sve dobro, državu i posebno nacionalna svojstva Rusije, značaj naroda ruskoga), veliki umjetnik, te je njegov književni nihilizam odraz duhovne i moralne krize vremena. Idealistički, afektivni prikaz Turgenjeva i njegovog snažnog umjetničkog i političkog djelovanja ujedno je i afirmacija slavenskoga sentimenta čiji je Turgenjev idealistički zastupnik: Pjesnik tuguje, jer je Rus, jer se je sva slovinska duša slila njemu u grudi. Melankolija njegova sjeća nas doista i turobnih bugarkinja naših. (ibid.) Jasmina Vojvodić (2020) ovaj Mažuranićev članak čita i kao pohvalu realizmu; ipak, emotivna, idealistička, emfatička i eksklamativna Mažuranićeva analiza Lovčevih zapisa i Očeva $i$ djece svjedoči da su se poetičke pretpostavke realizma u hrvatskom kulturnom prostoru 19. stoljeća prihvaćaju kontekstualno i procesualno: Mažuranić Turgenjeva naziva realistom, no čita ga idealistički. Zanimljivo, Turgenjev će umrijeti nekoliko mjeseci poslije ovoga članka, u rujnu 1883, te je članak, iz prezentističke perspektive, moguće tumačiti i kao preuranjeni nekrolog.

Iste je godine Vladimir Mažuranić u izdanju Matice hrvatske objavio dramu Grof Ivan, nagrađenu iz zaklade Dušana Kotura za godinu 1883. Dramu će Branko Hećimović opisati kao tendencioznu, neizvornu i neambicioznu melodramu, nastalu po uzoru francuskog romantičarskog kazališta, ali bez dramske snage: Mažuranićevo lociranje radnje u Podolje, na dobro Radovićevih, kao da samo po sebi navodi na melodramatski sadržaj u kojem svoje mjesto nalaze raznovrsni $i$ već dobro poznati instrumentarij, kao što su mladi rasipni i neodgovorni plemić, skromna i siromašna djevica s tajnovitom prošlošću, roditeljski grijesi, fatalna žena, stranac varalica, Židov lihvar, intrige, 
dvoboj, podmetnuto pismo, pokušaj samoubojstva, krivotvorenje mjenica, pošteni i pravdoljubivi prijatelj, te komične figure, rodoljublje, pobjeda pravde i sretni svršetak. (Hećimović 2000: 234)

Ovom se lucidnom opisu može još dodati nekoliko ponešto originalnijih ili zanimljivijih motiva, poput, primjerice, nepropuštanja prilike da se usputno i nevezano uz glavnu radnju, negativno ocijeni ženska emancipacija. Skromna i siromašna djevica s tajnovitom prošlošću - središnje žensko lice drame - u svoja intimna razmatranja koja će pošteni i pravdoljubivi prijatelj kriomice pročitati, bilježi i antiemancipatorske sentimente: Što će mi svi ti razlozi za emancipaciju, kad mi duša šapće, da žena, koja ljubi supruga, mati, koja živi u djetetu, nebi znale, što da počnu s dužnostmi javnimi, kraj tako sladkih obveza obiteljskih. (Mažuranić 1883b: 17) Mažuranić iz 1870-ih koji je javno zagovarao žensko obrazovanje i emancipaciju u 1880-ima se, izgleda, ponešto predomislio.

Godine 1884. Mažuranić je u Viencu književno najaktivniji: u trećem je broju objavio pjesmu Napast, u 6. broju dvije pjesme, te od 22. broja u pet nastavaka šaljivu igru pod naslovom Anarkiste.

Mažuranićeva objavljena poezija - tri pjesme s naslovima Napast, Orle moj i Na grobu - u kontekstu njegovog književnog stvaranja gotovo da bi se mogla tumačiti iz perspektive ogledanja u književnim rodovima: uz esej i dramu, pokušaj u poeziji. Izostavljanje fikcijske proze - kompatibilno i očevu književnom radu koji je u fikcijskoj prozi napisao samo (vrlo kratku) alegorijsku crticu Slavulj i kukavica (1835) - ujedno odražava i devetnaestostoljetnu hijerarhiju književnih vrsta, u kojoj prozi pripada posljednje mjesto. Idealizam i tankoćutnost kasnog 19. stoljeća - koje će, doduše, već za koju godinu osporiti modernistički poetički izazovi, najjasnije se ogledaju u poeziji. U tom je kontekstu zanimljivo spomenuti da će Vladimirova kći Ivana Brlić-Mažuranić i tridesetak godina poslije - u predgovoru svoje Knjige omladini iz 1923. - još uvijek tvrditi da hrvatska književnost svoj prozni, pripovjedni jezik tek treba izgraditi. U Mažuranićevim je pjesmicama jezik izgrađen i osjećaj za pjesmovni oblik naglašen, dok je tematski repertoar konvencionalan: jedna tužaljka nad tragičnim usudom nepoznate žene, jedna gorljiva pohvalnica idealiziranoj muškoj figuri („orle moj”) čija je tragična sudbina očito povezana s hrvatskim političkim usudom (izdaja, tragedija, pobratimstvo) te najzanimljivija i tematski najzačudnija pjesma Napast, u kojoj je plavokosa kćerka miljenica svojom pojavom satrla pjesnikove napasti, možda i očaj zbog gubitka djeteta, s obzirom na motiv „bolnog odra”. Godine 1884. starija je Vladimirova kći deset godina stara, 
dok je mlađa šestogodišnjakinja, te se iz pjesme ne razabire kojoj se pjesnik obraća.

Svoj najdulji književni prilog u Viencu, šaljivu jednočinku u pet prizora Anarkiste Mažuranić piše očito u kontekstu živoga zanimanja, pa i panike javnosti pred anarhizmom i njegovom divljačkom elokvencijom dinamita, kako je naziva francuski povjesničar anarhizma Aleksandre Skirda (prema Pejić 2016: 129), ujedno i u kontekstu povišenog negativnog raspoloženja građanskog tiska ne samo prema anarhizmu, nego i socijalističkom pokretu uopće. Povjesničar hrvatskoga anarhizma Luka Pejić navodi nekoliko primjera iz zagrebačke štampe početkom 1884. u kojima se jasno razabire demonizacija revolucionarnih pokreta, uključujući i tvrdnje kako „socijalistička agitacija 'ugrožava temelje društva"' (Pejić 2016: 89).

Mažuranićeva je šaljiva igra izlazila od 22. do 26. broja Vienca u 1884. godini: prema Bibliografiji Vienca (Anon.) ti su brojevi izlazili u lipnju. Zanimljivo je primijetiti da je u proljeće iste godine Zagreb bio živo zainteresiran za anarhizam i radničko organiziranje: naime, kako piše Pejić, u veljači 1884. u Zagrebu su uhapšena četvorica anarhista koji su raspačavali anarhističku literaturu i zagovarali radničko organiziranje - Franjo Srnec i Wolfgang Hiža kao glavni optuženici, te Vjekoslav Montanelli i Izidor Straub kao suradnici. Tijekom ožujka pripremljena je optužnica protiv njih, ban Khuen-Héderváry šalje okružnicu svim načelnicima upozoravajući na opasnost od radničkog organiziranja i anarhizma (Pejić 2016: 90), a u svibnju je vođen sudski proces, koji je završio presudom na nekoliko godina teškog zatvora za glavnu dvojicu i izgon iz države nakon odslužene kazne. Dvojica glavnih optuženika bili su stranci - četrdesetpetogodišnji postolar Srnec bio je podrijetlom iz Štajerske, krojač Hiža, 59 godina star, iz Moravske, a za Montanellija i Strauba podrijetlo je nepoznato. Tijekom svibnja zagrebačke su novine iscrpno i slikovito pisale o optuženicima i njihovim zlodjelima, između ostaloga opisujući vanjski izgled Srneca i Hiže: zagrebački Pozor, kako prenosi Pejić, Hižu opisuje kao ćelavog starca dugačke brade koji učini na čovjeka utisak prije kao neki patrijarkalni starina koj živi u miru i zadovoljstvu u krugu svoje djece i unučadi, nego li kao čovjek, koji želi sa svimi postojećimi uredbami učiniti tabula rasa i sve potopiti u krvi, pa podići novi red na ruševinah sadašnjih modernih država (prema Pejić 2016: 91), dok je Sloboda nešto naklonjenija optuženim anarhistima, opisujući ih sa simpatijama: Hiža je star čovjek od 59 godina, cielo tielo i sav izgled odaje čovjeka bolestna, a izražaj lica mu je osobito zanimiv. Budući upravo bolestan, izgleda vrlo satrven. Hiža pobudjuje u obćinstvu sućut. Obtuženik Srnec star 45 godi- 
nah, čovjek bi ga držao mnogo starijim, jer je već jako osiedio. Lice i pogled odaje čovjeka, koji je mnogo trpio. Ostala dvojica su mladići od 22 godine, vanjština im je simpatična i inteligentna. (prema ibid.)

Živ interes tiskovina za izgled optuženih odražava tjeskobnu znatiželju građanskoga društva prema anarhizmu i anarhistima: može li se prema izgledu zaključiti ponešto o radikalnoj, prevratničkoj, zastrašujućoj misli koju tako gorljivo zastupaju? Nešto se od te znatiželje, ali i imagološke tromosti i stereotipije u kontekstu anarhizma, ogleda i kod Mažuranića, koji je, vjerojatno, Anarkiste pisao upravo u vrijeme aktualnoga suđenja zagrebačkim anarhistima. Tanak se dramski zaplet Mažuranićeve šaljive igre odnosi na paniku građanskoga društva pred neredom anarhizma: u neimenovani gradić stiže vijest o bijegu opasnoga anarhiste naoružanog dinamitom („nosi bombu u kovčegu"). Strah i tjeskobu pred kaotičnom prijetnjom anarhizma personificira nesposobni i karikirani detektiv koji posumnja na neznanca s tajanstvenim kovčegom koji se smješta u lokalni pansion u pratnji mlade žene. Neznanac je, međutim, pasionirani arheolog amater (paleoantropolog, kako sam sebe naziva) koji putuje s kćerkom. Podzaplet uključuje, dakako, sentimentalnu romantičnu liniju, niz nesporazuma i završnu, komičku katarzu u kojoj se svi labavi dramski čvorovi razrješavaju, a fantomski anarhist uhvaćen je negdje u dalekom svijetu. Aktualan onodobni interes - ili, bolje, strah - od anarhista, u komediji je eksploatiran na nekoliko razina: od opisa anarhista u potjernici koja stiže u gradić, a u kojoj je odbjegli revolucionar, njeki starac, najpogibeljniji anarkist opisan kao Nepoznata imena, srednjega stasa, duga nosa, smedjih očiju, ćelav, hramlje malo na desnu nogu, govori njemački, talijanski (Mažuranić 1884: 343), koji nosi sa sobom bombu u kovčegu, preko veličanja policijskih uspjeha u suzbijanju opasnosti anarhizma, pa do leksičkoga poigravanja značenjskim rasponom pojma anarhizam i anarhisti. Osumnjičeni arheolog-amater tako samoga sebe opisuje kao anarhista, osporavatelja autoriteta u kontekstu paleoantropologije: Što se tiče paleantropologije, tu ne poznam auktoriteta, ja si sam krčim put - u boj - ja sam anarkista! (ibid.: 395). Djelovanje anarhista brižljivo je dekontekstualizirano i izdvojeno iz političke sfere - oni svojim akcijama predstavljaju opću opasnost za populaciju, njihova je agenda iracionalna, u njima nema privrženosti ni za što (kako to formulira detektiv, oni nemaju kćerke), i u svemu su prijetnja građanskome redu i poretku.

Branko Hećimović ovu će Mažuranićevu komediju proglasiti satiričnom, odrediti kao osrednje uspješnu, no vremenski, prostorno i uopće povijesno određeniju od autorovog dramskog prvijenca, povezujući Anarki- 
ste i s Gogoljevim Revizorom i s Nušićevim Sumnjivim licem, te uočavajući niz dodirnih točaka upravo s Nušićem, čijoj komediji Anarkiste prethode, u oblikovanju dramskih lica policajaca i njihovoga ponašanja. Zanimljivijom se, međutim, od slabašne dramske dinamike i predvidljivog zapleta, doima autorova aktualnost, kao i političan podtekst njegova dramskog pisma. Anarhizam je u 1870-ima i 1880-ima važna dnevno-politička i filozofskopolitička tema. Početkom 1870-ih hrvatski gradovi počinju sve više rasti, što se, dakako, odnosi najviše na radničku populaciju, koja se u to vrijeme počinje i organizirati. Anarhističke ideje ostaju manjinske među hrvatskim radništvom, no europske anarhističke poruke i akcije, ponajviše radikalan koncept propagande djelom odnosno nasilnih, bombaških napada na istaknute figure kapitalističke eksploatacije i državne ili monarhijske vlasti, ili pak na simbole građanskog reda i kulture, prilično glasno odjekuju i u Hrvatskoj, što je u skladu s javnim diskursom o anarhizmu u to doba, koji Ana Rajković (2018: 69) opisuje kao „jednoobrazno[g] prikazivanje anarhizma isključivo u konturama nasilnih akcije (sic!) odnosno metode propagande djelom, koja je prevladavala početkom 1880-ih godina”. Zanimljivo je, nadalje, u tom kontekstu, da će se propaganda djelom, koju Mažuranić u komediji prezentira kao udaljenu, ponešto karikiranu i grotesknu opasnost, već sljedeće godine pojaviti opasno blizu, i to u Slavoniji, gdje će se bravarski pomoćnik Ignjat Graff, prognan u studenom 1884. iz Szegedina u Slavoniju zbog posjedovanja anarhističkog tiska, u lipnju 1885. u Osijeku naći pred sudom iz istoga razloga: posjedovanja anarhističkog tiska, i to, između ostaloga, i inkriminiranog lista Freiheit Johana Mosta, najradikalnijega zagovornika propagande djelom, i to u količinama namijenjenima daljnjoj distribuciji, ali i zbog uputstva za izradu dinamita (Rajković 2018: 79-81). Ana Rajković pažljivo kontekstualizira Graffovo djelovanje i zaključuje da su uputstvo za izradu dinamita i druge anarhističke tiskovine koje je Graff posjedovao odnosno koje su mu bile upućene u poštanskoj pošiljci koju je policija presrela i otvorila, jasan signal Graffova aktivnog podržavanja anarhističke akcije i propagande djelom. U svjetlu ovoga podatka, Mažuranićev „salonski” smijeh anarhizmu ne doima se potpuno depolitiziranim. Premda u Hrvatskoj sve do drugog desetljeća 20. stoljeća nije bilo političkih atentata, već i spomenuta suđenja mogla su djelovati na osjećaje straha, nesigurnosti i iracionalnosti pred djelovanjem anarhista pod čijim se utjecajem oblikuju predodžbe o divljim, neukrotivim, a u ponekim opisima i luđačkim anarhistima čija je politička agenda usmjerena isključivo mržnjom prema bogatima i lijenošću. 
Mažuranić, koji se kaosa i nereda anarhizma grozio i u članku o Turgenjevu, u svojoj komediji dekompenzira sve spomenute stereotipe $u$ humornoj gesti, no tjeskobni je intertekst ipak uočljiv u nabrajanjima bombaških napada i u resemantizacijama riječi dinamit u dramskom otvaranju. Ujedno, završno katarzično hvatanje odbjegloga anarhista u nekom udaljenom europskom velegradu jasno upućuje na utjehu hrvatskog položaja europske provincije koji nas u ovom slučaju čuva od anarhističke opasnosti.

Mažuranićevi Anarkiste do danas će ostati prilično usamljeni u hrvatskoj književnosti u kontekstu teme anarhizma; sporedni, uzgred spomenuti likovi anarhista pojavit će se kod Matoša ${ }^{3}$, o anarhizmu će rubno progovoriti i Šimić ${ }^{4}$, August Cesarec $^{5}$ i Krleža ${ }^{6}$, no ne i Kamov, čije se književno djelovanje pokatkad asocira i anarhizmom, no koji, koliko je poznato, nije čitao anarhističku literaturu niti se zanimao za anarhističku političku ideju (Pejić 2016: 178). Premda će i nakon Anarkista surađivati u Viencu oko književnoga rada svojega ujaka Demetra, Mažuranić će ovom komedijom zaokružiti svoj literarni opus. Prema Hećimovićevoj ocjeni, za hrvatsku dramsku književnost njegovo odustajanje od pisanja ne predstavlja osobit

3 Matoš u pripovijetki Camao svojega Alfreda Kamenskoga u mahnitom lutanju vodi posvuda po Europi - od Beča, Pešte, Zagreba, potom Ženeve, Berlina, Varšave i Kristijanije, do Pariza i Belgije. U Varšavi druguje s anarhistom Majevskim, s kojim je i protjeran u Bruxelles. Majevski „bijaše dobar kao med i hrabar kao lav. Stanovasmo zajedno. Njegovo me sedmogodišnje zlatokoso gupče vazda čekalo kada sam dolazio sa sviranja i usnulo mi o vratu. Majevskom davah novac da gradi dinamit. Jednog večera idem kući da sviranja i odjedared tresak, prasak, ršum, urnebes! Padnem ničice. Dinamit raznio pola našeg hotela." (Matoš 1967: 173). Kamenski potom s gimnastičarem Griffithom bježi iz Londona u Španiju, gdje svjedoči pogubljenju garotiranih anarhista (ibid.). I u pripovijetki $U$ čudnim gostima (1898) Matoš piše o anarhistu Špiri Laziću, članu aktivne anarhističke ćelije; a i izvan fikcijske književnosti pozitivno ocjenjuje anarhizam i za života u Parizu surađuje s anarhističkim glasilima (Pejić 2016: 172-174).

4 Šimić je 1918. godine objavio esej Anarhija u umjetnosti, pozitivno ocjenjujući anarhiju koju vidi kao slobodu i kreativnost u umjetnosti, te utvrdivši da „anarhija drma temeljima konvencionalnosti” i da „samo iz anarhije, koja je sva kretnja, i koja je sva život, može da se rodi život" (Šimić 1963: 109-110).

5 Luka Pejić navodi istraživanja Zorice Stipetić koja u ranim Cesarčevim zapisima prepoznaje promišljanja o anarhizmu i podržavanje anarhističkih postulata, v. Pejić 2016: 176-177.

6 O odnosu Krleže prema anarhističkoj misli piše Suzana Marjanić (Glasovi davnih dana: transgresije svjetova u Krležinim zapisima 1914-1921/22. Zagreb, Naklada MD, 2005). Marjanić navodi Krležine očite simpatije prema Kropotkinu, kao i prema tekstovima Maxa Stirnera. 
gubitak. Ipak, imajući u vidu stilski pluralizam i poetološke i poetičke mnogolikosti kasnog 19. stoljeća, Mažuranićev skroman književni opus svakako vrijedi zabilježiti, pa makar i samo zbog uvođenja teme anarhizma u diskurs visoke kulture.

\section{Literatura}

Anon. Bibliografija Vienca. https://www.matica.hr/media/uploads/bibliografije/13_vienac_1869-1903.bibliografija.pdf.

Budimir, $\mathrm{M}^{* * *}$ [Mažuranić, Ivan] (1835) „Slavulj i kukavica.” Danicza I (16): 64.

Hećimović, Branko (2000) „Vladimir Mažuranić i kazalište”. Dani Hvarskoga kazališta, 26, 1, 229-239.

Jureković, Marino (2015) Mažuranić, Vladimir. Hrvatski biografski leksikon. Zagreb: Leksikografski zavod Miroslav Krleža. http://hbl.lzmk.hr/ clanak.aspx?id=11879.

Mandušić, Iva i Ankica Šunjić (2015) Ivan Mažuranić. Hrvatski biografski leksikon. Zagreb: Leksikografski zavod Miroslav Krleža. http://hbl.lzmk. $\mathrm{hr} /$ clanak.aspx?id=11878.

Maretić, Tomo (1904) I. S. Turgenjev u hrvatskim i srpskim prijevodima: kritičko-bibliografički pregled. Zagreb: [s. n.].

Matoš, Antun Gustav (1967) Pjesme, pripovijesti, autobiografija. PSHK, knjiga 64. Zagreb: Zora, Matica hrvatska.

Mažuranić, Vladimir (1870) „Tudja književnost naprama našem narodu”. Vienac II (16): 249-254.

Mažuranić, Vladimir (1871) „O socijalnom stanju žena”. Vienac III (15): 234-239.

Mažuranić, Vladimir (1883a) „Ivan Turgenjev i nihilizam”. Vienac, XV, 19, 308-311.

Mažuranić, Vladimir (1883b) Grof Ivan. Igrokaz u pet čina. Zagreb: Naklada Matice hrvatske.

Mažuranić, Vladimir (1884a) „Napast.” Vienac XVI (3): 33.

Mažuranić, Vladimir (1884b) „Orle moj.” i „Na grobu.” Vienac XVI (6): 85.

Mažuranić, Vladimir (1884c) „Anarkiste. Šaljiva igra u jednom činu.” Vienac XVI (22): 341-344; (23): 357-359; (24): 375-377; (25): 393-395; (26): 405-408. 
Ograjšek Gorenjak, Ida (2006) „Otvaranje ženskog liceja u Zagrebu.” Povijest u nastavi, IV (8): 147-176.

Pejić, Luka (2016) Fragmenti subverzije. Historija klasičnog anarhizma u Hrvatskoj. Zagreb: DAF.

Rajković, Ana (2018) „Počeci kreiranja anarhističkog narativa u kontekstu slavonskog radničkog pokreta (1881-1914)." Historijski zbornik LXXI (1): 61-86.

Šimić, Antun Branko (1963) Pjesme i proza. PSHK, knjiga 99. Zagreb: Zora, Matica hrvatska.

Vojvodić, Jasmina (2020) „O recepciji ruske književnosti u Viencu.” Kolo, 1. https://www.matica.hr/kolo/603/o-recepciji-ruskeknjizevnosti-u-viencu-30185/.

Zima, Dubravka (2019) Praksa svijeta: biografija Ivane Brlić-Mažuranić. Zagreb: Naklada Ljevak.

Župan, Dinko (2005) „Viša djevojačka škola u Osijeku (1882.-1900.)” Scrinia Slavonica, 5 (1): 366-383.

Župan, Dinko (2013) Mentalni korzet: spolna politika obrazovanja žena u Banskoj Hrvatskoj (1868.-1918.). Osijek, Slavonski Brod: Hrvatski institut za povijest.

\section{SUMMARY}

Dubravka Zima

\section{ANARKISTE U VIENCU: VLADIMIR MAŽURANIĆ'S LITERARY OPUS}

The paper deals with the literary opus of Vladimir Mažuranić, who published several essays and poems and one play in the Vienac magazine in the 1870's and the 1880's. In 1883 he also wrote a play titled Count Ivan, which won an award from Matica hrvatska. Mažuranić wrote about women's issues (education, legal rights etc.) and Russian literature (Turgenev). In 1884 he wrote a comedy about anarchism, which was a major social and political topic at that time. It is interesting to notice that Mažuranić wrote this comedy during the Zagreb anarchists' trial which attracted major public attention.

Key words: Vladimir Mažuranić; Vienac; nihilism; Turgenev; anarchists; anarchism 